\title{
The Effect of Local-Based 2013 Curriculum Implementation on Students' Environmental Awareness
}

\author{
Dwi Purwanti ${ }^{1}$, Gunarhadi², Akhmad Arif Musadad ${ }^{3}$
}

\begin{tabular}{l} 
ARTICLE INFO \\
\hline Article History: \\
Received 02.09.2018 \\
Received in revised form \\
21.11 .2018 \\
Accepted \\
Available online 01.01 .2019
\end{tabular}

\begin{abstract}
Local-based 2013 curriculum encourages to raise students' awareness. The purpose of this study is to describe the need for 2013 curriculum learning syllabus in elementary schools, the procedures for developing the local-based 2013 curriculum learning syllabus, and the effectiveness of local-based syllabus to develop environmental awareness. This research used research and developmental method. This developmental research was conducted on thematic learning in four grade of Elementary School in Surakarta, Central Java in the 2017/2018 academic year. The data were collected through observation, documentation, and interviews. The data analysis used triangulation by combining information from various sources and data collection techniques. The results of this study showed that there is a need on sy llabus with suitable material for the development of students and the local-based materials contained in the syllabus is placed in the development of indicators and learning activities in the syllabus product. The development of local-based material is perceived more complete than the official syllabus material and still in line with the theme or sub-theme. After using the local-based syllabus, teachers can provide character values that can be taken by students. Generally, the syllabus used by most teachers has met the standards but is not yet fully local-based, so the local-based syllabus will be a creative and innovative alternative in realizing students' caring attitudes especially toward the environment.
\end{abstract}

Keywords:

2013 Curriculum, Local-Based Syllabus, Environmental Awareness

\section{INTRODUCTION}

Education is a basic need that is absolutely necessary for all levels of society. The educational crisis can cause a multidimensional crisis. Humans are born carrying three psychological potentials, namely creativity, taste, and intention. Those potentials continue to be developed in the existence of life so that humans are classified as educational beings (Kutanegara, 2014). To develop schools as learning organizations, the Indonesian Ministry of Education and Culture developed the School Literacy Movement (GLS). One of the activities in the movement $w$ as " 15 minutes reading non-subject books before the learning time began". This activity is carried out to foster students' interest in reading and improve reading skills so that know ledge can be mastered better. The scope of the School Literacy Movement covers a variety of physical, social and academic environments. That movement is embedded in the national curriculum namely the 2013 curriculum. The 2013 curriculum has four aspects of assessment, namely aspects of knowledge, skills, attitude, and behavior. Those assessments are based on the core and basic competencies for each school level.

In the 2013 elementary school and Islamic elementary school curriculum, core competencies and basic competencies are the direction and foundation for developing subject matter, learning activities and indicators of achievement of competencies for assessment (Kemendikbud, 2013). In accordance with the research that will be carried out, the core competencies that are included in the 2013 curriculum in Elementary Schools covers many items of competency. The core competencies of the 2013 curriculum (Kemendikbud, 2013)are: (1) to accept and carry out the teachings of the religion they adhere to, (2) to demonstratehonest, disciplined, responsibility, politeness, caring, and confident behavior in interacting with family, friends, teachers and neighbors, (3) to understanding factual knowledge by observing (hearing, seeing, reading) and asking based on curiosity about himself, God's creatures and activities, and the objects he encounters at home and at school (4) to present factual knowledge in clear and logical language, in aesthetic work, in movements that reflect a healthy children, and in actions that reflect a faithful and noble behavior. 
The above statement is strengthened based on the observations carried out in some fourth-grade teachers of state elementary schools in Pasarkliw on Subdistrict, Surakarta City, Central Java, who used the 2013 curriculum. The interview results from 8 teachers show that students are not accustomed to doing environmental care without the teacher's instructions. It means that the direct involvement of students in environmental caring is very low. It is also found that teachers or other parties are lack of motivation in fostering environmental aw areness characters. Those facts are interpreted as the need for environmentallybased learning tools. The results of questionnaires from 8 teachers in state elementary schools in Pasarkliwon subdistrict that use the 2013 curriculum also support the discussion. Many elementary schools in Pasarkliw on Subdistrict are still lacked in local-based learning implementation. The 2013 curriculum is still in its trial period and only applied in little a number of schools to become pilot schools.

The character of environmental aw areness is the attitude and actions that alw ays strive to preserve the surrounding environment (Suyadi, 2013). The character of environmental aw areness must be formed in each individual so that individuals can maintain and preserve the environment (Al-Anw ari, 2014). Environmental aw areness can start with each person through simple actions. Environmental aw areness characters can be integrated into learning in each subject (Hamzah, 2013). This is in accordance with the recommendation of the Indonesia Ministry of Education \& Culture (Kemendikbud, 2013) that the development of national culture and character can be integrated into subjects, self-development, and school culture. Culture is essentially a combination of various elements of human life so that in cultural inheritance we must involve the existing human mindset (Ardiansyah, Suharno \& Triyanto, 2018). Learning materials related to the values in each subject need to be developed and explicitly linked to the context of everyday life (Hosnan, 2014). The environment-based syllabus is a teacher's guide to teaching in elementary schools that implement the 2013 curriculum, especially to improve environmental aw areness. Through the local-based syllabus in 2013 curriculum, hopefully, a strong character can be formed in students. A character is a characteristic of someone who distinguishes quality between individuals. A character is not only what is seen on the surface, but more deeply, namely the individual's personality. This statement was supported by (Bohlin, 2005) which stated, "Character that is the distinctive mark of our person; the combination of these distinguishing qualities that make us who we are. Character is more than our personality or temperament.

However, in fact, the character of the students are still less, especially in matters of caring and discipline. This can be seen from the lack of concern of students, especially the concern for the environment. The ignorance of the environment is reflected in the attitude of students who still like to throw garbage carelessly, scribble on walls or tables, and do not want to clean the environment around the school. The concern on the environment should be developed as early as possible because it cannot grow by itself. According to many scientists, the reason for students on not behaving sustainably about environmental problems is their limited knowledge on the environment and their inability to consider results of their actions. In some of the related studies, environmental knowledge is not effective in increa sing aw areness and related behavior (Keleş, Uzun, \& Varnacı-Uzun, 2010). Even though the little relationship observed reveals that the knowledge possessed by the students does not influence their attitude tow ards the environment, the learning activity should still concern on this section, especially by practicing, since it will create a common sense and better behavior (Aminrad, Zakariya, Hadi, \& Sakari, 2013).

Therefore, researchers tried to provide solutions by making learning tools in form of a syllabus. It hopefully can be a teacher's guide so they can transfer material or characters that students supposed to be mastered. A syllabus is a learning plan in a particular group and subject that includes competency standards, basic competencies, subject matter, learning activities, achievement of competencies indicators for assessment, time allocation, and learning resources (Trianto, 2010). According to (Çimen \& Yılmaz, 2014) in developing the syllabus there are steps that need to be taken. They are identifying problem and needs, analyzing problems, selecting topics, selecting formats, formulating, editing and revising. Learning tools such as syllabus will greatly assist teachers in planning and conveying the process of seeking knowledge to students. Borich (2007) states "Planning is the systematic process of deciding what and how your students should learn". Planning is a systematic process for deciding what and how students should learn. However, in reality, the state elementary schools in Pasarkliw on subdistrict still experience problems related to the development of these learning tools. One of the problems that arise is that a learning tool has not been developed to accommodate character development. Based on the results of observations on students' 
Purwanti,D., Gunarhadi \& Musadad,A.A. (2019). The effect of local-based 2013 curriculum implementation on students' environmental awareness. International Journal of Educational Research Review,4(1),65-75.

environmental aw areness in the state elementary schools that have not developed a fourth-grade elementary learning tools based on scientific approach, the students' attitude is still lack and it will be a great potential problem to build caring character.

Table 1. Observation results of environmental aw areness attitude

\begin{tabular}{|c|c|c|c|c|c|c|}
\hline \multirow{2}{*}{$\begin{array}{l}\text { Aspects of Environmental } \\
\text { Awareness }\end{array}$} & \multicolumn{4}{|c|}{ Rating } & \multirow[t]{2}{*}{ Average } & \multirow[t]{2}{*}{ Categories } \\
\hline & 1 & 2 & 3 & 4 & & \\
\hline $\begin{array}{l}\text { Cooperation to protect } \\
\text { nature }\end{array}$ & 7 & 49 & - & - & 1.88 & Low \\
\hline $\begin{array}{l}\text { Respecting cleanliness and } \\
\text { health }\end{array}$ & - & 32 & 24 & - & 2.45 & Low \\
\hline $\begin{array}{l}\text { Wise in using natural } \\
\text { resources }\end{array}$ & 25 & 32 & 27 & - & 2.02 & Low \\
\hline $\begin{array}{l}\text { Environmental } \\
\text { responsibility }\end{array}$ & 27 & 43 & 12 & - & 1.73 & Low \\
\hline
\end{tabular}

Based on the above preliminary explanation, the environment-based syllabus is needed in order to implement the 2013 Curriculum and character development as the teacher's reference to teach. Therefore, it is necessary to develop learning tools based on scientific approach (Saminanto, 2013) in order to build caring characters, especially toward the environment. Environmentally aware and empowered youths are potentially the greatest agent of change for the long-term protection and stew ardship of the environment (Erhabora \& Don, 2016). This is the basis that makes the environmental aspect is necessary to be included in the syllabus. Research conducted by Finn (2011) entitled Critical Thinking: Knowledge and Skills for Evidence-Based Practice showed that improvement in learning tools such as syllabus can effectively gain the student' skill mastery. It will be useful for the teacher in conducting project-based learning situation. Environmental concern also can be embedded in many learning methods. Many modern methods can be used in developing environmental awareness so that teachers become the strongest parts of fostering this aspect. The environmental-based syllabus will drive the primary school teacher perceptions towards environmental problems and permanency of learning and then transfer it to their students (Uyanik, 2016). To attach character of caring the environment in the classroom, school need to develop many tools to provide a guideline (Al-Anwari, 2014) and the environmental-based syllabus can be a positive solution. Learning practices which addressed environmental problems also can increase students' environmental behavior positively (Şimşekli, 2004).

\section{METHOD}

This research is a developmental research. The development model in this research and development follows the ADDIE design. ADDIE stands for Analysis, Design, Development, Implementation, and Evaluation (Branch, 2009). The ADDIE model was developed to design a learning system (Mulyatiningsih, 2011). The elaboration of the five stages of development adopted in this study is as follow: (1) Analysis is the performance is done to find out and clarify whether the problem faced requires a solution in the form of the implementation of learning programs or improvement management. (2) Design is efforts to investigate learning problems faced. (3) Development is activities to create and modify local- based syllabus. (4) Implementation is to test the effectiveness syllabus by users in the field. (5) Evaluation is as a process carried out to provide an assessment to learning programs. The data collection techniques in this study are using interviews and observations made on students and teachers of the fourth-grade elementary schools in the Pasarkliw on sub-district, Surakarta. In this study, the syllabus developed is implemented in 52 elementary schools in the area of Pasarkliw on sub-district.

The product trials in this developmental research aim to refine the product by practicing it directly in the targeted field. The trial was carried out through the stages: (1) preliminary field test (small group trials with the one-shot study method); (2) main field test (field trial with one group pretest-posttest method); and 
(3) effectiveness test (effectiveness test with Quasi-experimental method). The subjects in the study were all the fourth-grade students of 52 elementary schools in Pasarkliw on sub-district.

In the design and development stages, several instruments were used for data collection, namely observation with product assessment guidelines to obtain data on the validity of syllabus from material and curriculum experts. Validation sheets were used to determine the effectiveness of the syllabus produced. In addition, in the evaluation stage, also used rating scale to observe the character of discipline and care that arise in students in the learning process during the main field and effectivenes s tests. This rating scale uses a Likert scale with five scale criteria. This observation was carried out during the preliminary field and effectiveness tests.

The interview instrument is also used to supplement the data obtained from observations. This instrument is used at the initial information gathering in the analysis stage. The interviews used were closed interviews to gain information and explanation from the research subject about the 2013 curriculum implementation and the problems associated with the 2013 curriculum implementation (Majid \& Rochman, 2015). In the field test phase, this instrument was used to obtain opinions from the teacher regarding the suitability of the material about the natural environment. The questionnaire is used to obtain teacher responses to assess the effectiveness of products developed and students 'responses to obtain data regarding students' opinions about the learning process experienced. Score determination is made on a scale of five. The data analysis technique used is descriptive data analysis, to describe quantitative data conducted by analyzing the observation data. The quality of the syllabus draft was compiled and analyzed by material experts, and curriculum experts prior to the preliminary field test, main field test, and effectiveness tests. Based on the three test results obtained a number of quantitative data. The data is then analyzed to obtain the expected final research product, which is in the form of a local-based scientific approach syllabus to build the character of the natural environment aw areness.

Aw areness improvement analysis was carried out to determine the effect of learning devices on the results of the pre-test and post-test through observations of students' characters. The rating scale of the character of discipline and awareness filled by observers resulted from the average score to be analyzed. Analysis of differences in aw areness character was also carried out to find out the increase of the character of environmental concern in the experimental class and the control class. The prerequisite test that must be met before the $t$-test is the normality and homogeneity test. The normality test is done to find out whether the data from each variable is normally distributed or not. The normality test is carried out on the standard of character of awareness. The normality test was carried out using the Kolmogorov-Smirnov test. The homogeneity test was aimed to find out whether the data is in the group experiments and control groups have the same variance or not. Homogeneity variance test is performed on data of disciplined and caring character.

\section{RESULT AND DISCUSSION}

\section{The need of local-based syllabus on the 2013 curriculum}

The standard of 2013 curriculum syllabus has changed or revised in 2017. Although it has been revised periodically, the syllabus still has many weaknesses. One of them is how the syllabus can attach the learning activity based on local wisdom. The evidence appeared in interviews in preliminary studies conducted at several state elementary schools that used the 2013 curriculum in Pasarkliw on Subdistrict, Surakarta City. It can be concluded that the existence of a local-based syllabus is very necessary for various educational institutions, especially the elementary grade. Based on the need analysis, some additional syllabus details should be included in the development of an environment-based syllabus. The syllabus developed should be: (1) complete, having clear material content; (2) easy, material is easily understood and implemented by the teacher: (3) Having a concrete learning method and strategy; (4) adding structural and unstructured tasks to students to raise aw areness of the surrounding natural environment; and (5) facilitating the teacher in increasing the level of environmental concern of students in daily life.

Based on interviews conducted at several state elementary schools in Pasarkliw on sub-district which were designated as the pilot school of the 2013 curriculum, the need for local-based Syllabus in the 2013 
curriculum is because the necessary to add material content in accordance with the potential contained in each theme. The development of material contained in the environmental-based syllabus is suitable with the characteristics of students. Those way the environmental-based syllabus will be helpful in this section. The addition of learning methods related to the children's environment such as recycling used goods and using organic waste into compost is very necessary. The use of environmental-based syllabus among students is very helpful for teachers in fostering environmental aw areness, especially for elementary school students. The improvement on the standard official syllabus by additional environmental-based will increase the process of students classroom learning activity.

Some additional details that would be included in the development of the environment-based syllabus are related to the teaching materials. The syllabus should contain com plete and clear material content. It will be easily understood and implemented by the teacher. The syllabus also has a concrete picture of the method and strategic learning to make it become clear guidance. The learning activity is completed by structural and unstructured tasks for raising students' aw areness of the surrounding natural environment. These tasks will facilitate the teacher in increasing the level of concern of students in daily life.

The quality of the developed syllabus can be observed through the analysis of the revised syllabus document. The analysis is carried out specifically on the suitability of the material with core competencies, basic competencies, and indicators. The researcher takes some consideration on several sections. First, the feasibility of the material with the curriculum. Based on the literature studies on this component, the researcher found that the material $w$ as in accordance with core competencies and basic competencies, but there $w$ as still a slight change in core competencies in point 1 . The themes and sub-themes are mutual, but there are some repetitions in the syllabus. The contents of the environment-based syllabus already contain environmental concerns but the user creativity must still take the important part. The developed syllabus is in accordance with the community values so that have a support from parents.

Second, the development of indicators. Indicators in the official syllabus were developed by incorporating several methods and strategies leading to environm ental concerns. The indicators on each subthemes should be interconnected and sustainable. Each basic competence should provide several indicators that lead to environmental concerns. The third section is learning resources. Learning resources here include material sources, the source of media, and other learning resources. A variety of learning resources chosen should support the implementation of the environment-based syllabus. Books should not be the only material resources since it will be supported by internet, real media from environment and etc. Fourth, the presentation of the material in the student and the teacher's book on the theme of "My Living Environment". The researcher revised the incomplete material that leads to the activities of students or teachers in environmental care. The absence of skills assessment in the official syllabus is revised to activate attitudes of environmental care attitudes, such as adding structured tasks in making environment-based clippings through print or internet media.

Fifth, the scope of environmental aspects. In the material provided, the environmental aspect should emphasize the application and examples of the values and attitudes tow ard the environment as well as the presentation of the application in environmental aw areness. The combination of environmental concerns in scientific learning (Observing, Questioning, Trying, Reasoning, and Communicating) hopefully can strengthen the concept and drive the questions leading to high order thinking skill (HOTS). The Sixth section is the feasibility of language and graphic. In the official syllabus with the theme of "My Residence Area", the display is using Arial type font size 10 with single space in writing, it was revised since will not be feasible for students. The layout of material presented in students' book has been presented in an interesting manner but then still lack of information. Some information should be clarified to make clear and readable material.

The results of a local-based syllabus need analysis involving 6 teachers from 6 elementary schools in Pasarkliw on Subdistrict resulted that the official syllabus needs for several improvements on suitability. They are the suitability of syllabus content in accordance with the theme and the suitability of the $m$ aterial with the level of development of class students. The problem of feasibility of the contents related to the core competence and basic competence still need to be overcome. The presentation needs to be complemented by the development of supporting indicators and learning resources. 


\section{The Procedure of Developing the Local-Based 2013 Curriculum Syllabus In elementary Schools}

The basic procedure of designing the local-based syllabus is the findings of the literature study, preliminary study, and exploration stage. The design of the environment-based syllabus still uses the guidelines of the syllabus development from the Ministry of Education and Culture which is still adapted to the core competency standards and basic competencies of the syllabus. The development of this syllabus uses the environmental basis that is incorporated into thematic material. Many parts need to be considered in the process of developing the syllabus by incorporating new elements. Some aspects that need to be considered in developing an environment-based syllabus are analyzing environmental factors, looking at environmental damage due to human activities, the ignorance level of the community from the consequences of their actions, the insistence of life needs, lack knowledge about ecosystems, low concern for environmental sustainability, and lack of information about law.

The initial prototy pe design was initiated by looking at the basic competencies in official syllabus from the Ministry of Education. The next procedure is developing each basic competencies into several environmental-based indicators and mapping material based on the indicators found. The material is also adjusted with other components in the syllabus. As stated in the methodology, the steps in developing the new syllabus are preparing the initial draft based on preliminary studies, literature studies and findings in research, conducting draft validations which include expert's judgment and user validation, conducting preliminary field test and improvement, extending the test into main field test and product revision, and doing the effectiveness testing by extensive testing and improvement tow ard real target user.

The initial draft of the environment-based syllabus consists of 3 parts, they are opening part (includes an introduction, basic competence, subject matter and learning outcomes, and mechanization and syllabus development steps), main part (details of material or syllabus components per lesson) and closing part. After the initial draft is created, the draft is validated by several aspects by expert. In the expert validation, the researcher conducted the process by three curriculum, material and language experts in each aspect. Each expert has carried out the aspect they mastered in. The results of the curriculum expert assessment are as follows:

Table 2. Result of Content Validation

\begin{tabular}{clccccc}
\hline No & Criterion & \multicolumn{3}{c}{ Validator } & Total & Percentages \\
\hline 1 & Very Good & 15 & $\mathbf{2}$ & $\mathbf{3}$ & & 2 \\
2 & Good & 17 & 29 & 28 & 74 & $17.2 \%$ \\
3 & Fair & 1 & 4 & 3 & 8 & $74.7 \%$ \\
4 & Less & - & - & - & - & $8.1 \%$ \\
5 & Bad & - & - & - & - & $0 \%$ \\
\hline & Total & 33 & 33 & 33 & 99 & $0 \%$ \\
\hline
\end{tabular}

From the results of the table above, the percentages stated that the syllabus draft was qualified. $17.2 \%$ of the total score indicated that the draft was very then mostly the validator assumed that the draft was categorized as good with $74.7 \%$ of the total score. The minimum categories obtain was fair with $8.1 \%$ from total score obtained. There is no validator stated less and bad categories indicating that the product is well structured and good enough to be implemented theoretically. This result is obtained from aspects of the depth of the material, the accuracy of the independent task and assessment, suitability of the contents with the social context, how the content provided encourages the user's curiosity and the existence of appropriate learning resources.

Besides the content validation, the language presented in the draft of the syllabus was also validated. Language validation was carried out by several experts in the aspect of the effectiveness of sentence and grammar accuracy of the content. The language expert validation results can be seen on the table below. 
Purwanti,D., Gunarhadi \& Musadad,A.A. (2019). The effect of local-based 2013 curriculum implementation on students' environmental awareness. International Journal of Educational Research Review,4(1),65-75.

Table 3. Result of Language Validation

\begin{tabular}{lllcccc}
\hline No & Criteria & \multicolumn{3}{c}{ Validator } & Total & Percentages \\
\hline $\mathbf{1}$ & Very Good & $\mathbf{1}$ & $\mathbf{2}$ & $\mathbf{3}$ & & $7.4 \%$ \\
$\mathbf{2}$ & Good & 5 & - & 1 & 2 & $70.4 \%$ \\
$\mathbf{3}$ & Fair & 9 & 5 & 19 & $7.4 \%$ \\
$\mathbf{4}$ & Less & 1 & - & 1 & 2 & $14.8 \%$ \\
$\mathbf{5}$ & Bad & 2 & - & 2 & 4 & $0 \%$ \\
\hline & Total & - & - & - & - & $100 \%$ \\
\hline
\end{tabular}

From the results of the table above, we can conclude that the language presented in the draft was a good category since most of the result obtained $70.4 \%$ of those nine statements given was good. There were $7.4 \%$ stated presentations were enough and very good. The main concern on this validation $14.8 \%$ of the score obtained stated less. In several aspects the draft still needs revisions. Product Revision is based on the results of the validation stage. Both curriculum and language experts' suggestion is used to revise and develop the product. Overall the validation proses showed that the initial draft was good and ready to be implemented.

After the validation process, the preliminary test is used to gain the users' perception. The implementation of the preliminary test was carried out at State Elementary School of Kauman 27 Pasarkliw on Surakarta by using 10 students from four graders and two teachers. In this stage, the teacher tried to implement the environmental-based syllabus in the learning activity. The activity is observed through learning and observation of syllabus users.

Table 4. Result of Preliminary Field Test

\begin{tabular}{ccc}
\hline Categories & Score & Percentages \\
\hline Aspects have been implemented & 4 & $40 \%$ \\
\hline Aspects have not been implemented & 6 & $60 \%$ \\
\hline
\end{tabular}

The results in the table above show ed that generally there are 4 aspects that have been implemented by teachers in class. Those aspects are planning for learning to foster environmental awareness, enabling environment hygiene by providing a clean classroom, providing a model to care for the environment and create a variety of activities that lead to environmental care. From two teachers observed, there are 6 aspects that have not been implemented. The aspects which have not been appeared are attaching slogans or $\mathrm{w}$ arning related to the environment, giving a strong $\mathrm{w}$ arning on class, responding spontaneously to students question, giving direction about trash, giving examples of trash utilization, and giving structured task (clipping an information about care for the environment. After the learning activity, the students are also tested by environmental aw areness questionnaire. The results of observations of students' environmental aw areness in preliminary field test can be seen on the table below.

Table 5. Result of Students' Environmental Aw areness in Preliminary Field Test

\begin{tabular}{cccccccc}
\hline $\begin{array}{c}\text { Aspects of Environmental } \\
\text { Awareness }\end{array}$ & \multicolumn{4}{c}{ Rating } & Average & Categories \\
\hline Cooperation to protect nature & 7 & 4 & 3 & 4 & & Low \\
\hline Respecting cleanliness and health & - & 32 & 24 & - & 2.45 & Low \\
\hline Wise in using natural resources & 25 & 32 & 27 & - & 2.02 & Low \\
\hline Environmental responsibility & 27 & 43 & 12 & - & 1.73 & Low \\
\hline
\end{tabular}


All of the aspects of environmental awareness showed that students' level was low. It is because the aspects in the syllabus are not completely implemented. In the next test, the teachers were encouraged to implement all of the environmental contexts in the syllabus.

The next step was conducting the main field test. Main field Test this is carried out based on the revision of the suggestions of the users (Teachers) during the preliminary test. The trial is widely implemented in two schools, they areState Elementary School of Kedunglumbu and state Elementary School of Semanggi Kidul Pasarkliw on by using 16 students in each school. Through observations on the two teachers in the schools, it can be obtained as follows:

Table 6. Result of Students' Environmental Awareness in Main Field Test

\begin{tabular}{clcccc}
\hline No & Criteria & Kedunglumbu & Semanggi & Total & Percentage \\
\hline 1 & Very Good & 12 & 7 & 19 & $59.4 \%$ \\
2 & Good & 4 & 7 & 11 & $34.3 \%$ \\
3 & Sufficient & 0 & 2 & 2 & $6.3 \%$ \\
4 & Low & 0 & 0 & 0 & $0 \%$ \\
5. & Bad & 0 & 0 & 0 & $0 \%$ \\
\hline & Total & 16 & 16 & 32 & $100 \%$ \\
\hline
\end{tabular}

The results in the table above showed that if the teachers implemented all aspect of environmental aspects around the school, students' aw areness will categorize as good. in the table above, there are $59.4 \%$ of students categorized as very good in environmental aw areness and $34.3 \%$ is having a good attitude in the environment. It can be concluded that the product of syllabus can intervene the students' aw areness. After final revision related to some weaknesses during the preliminary and main field test, the product of environmental syllabus is obtained. The product of the local-based syllabus product consists of: (1) the opening section, containing: (a) attachment of the 2013 Minister of Education and Culture Regulation No. 65 concerning the elementary school syllabus. The attachments include introduction, basic competencies, subject matter of four graders learning, mechanisms and steps for developing syllabus, and development of local or regional syllabus; (b) basic competency mapping and indicators equipped $w$ ith theme mapping. (2) Main section, which includes (a) sub-theme (b) core competence, (c) the elaboration column of learning syllabus, basic competencies, indicators and its development, learning material, learning activities, assessment, time allocation, and learning resources. That format goes on to all sub-themes. (3) Closing section, which includes biographical data of the user or developer and its level of education.

\section{The effectiveness of a local-based syllabus}

The effectiveness test was conducted in the State Elementary School of Dadapsari and State Elementary School of Sampangan. Effectiveness testing activities are carried out by the experimental method with the normality test and homogeneity test as the prerequisites. The normality test is a test to prove that the population of the experimental and the control class is normally distributed. Then a homogeneity test was conducted to see samples from the control and experiment are having the same or homogeneous variance. The results of the normality test from the control group analyzed using the SPSS application showed that the score obtained both for pretest and posttest were greater than $\dot{\alpha}=0.05$ or sig. .> $\dot{\alpha}$. The result of the pretest $0.570>0.05$ and posttest $0.365>0.05$ so that the data were normally distributed. While the normality test in the experimental group using the SPSS application is known showed that the pretest and posttest are greater than $\dot{\alpha}=0.05$ or sig. $>\dot{\alpha}$, the pretest results $0.578>0.05$ and post-test $0.894>0.05$. Furthermore, the homogeneity test of the pretest obtained sig. $0.579>0.05$ while the posttest results in a sig. $0.067>0.05$. Both the data group were homogenous so that can be compared. 
Purwanti,D., Gunarhadi \& Musadad,A.A. (2019). The effect of local-based 2013 curriculum implementation on students' environmental awareness. International Journal of Educational Research Review,4(1),65-75.

Table 7. Result of T-test tow ard Students' Environmental Aw areness

\begin{tabular}{lcclccc}
\hline Group & N & Mean & $\begin{array}{l}\text { Std } \\
\text { Deviation }\end{array}$ & df & Sig (2-tailed) & $\begin{array}{l}\text { Mean } \\
\text { Difference }\end{array}$ \\
\hline Control Group & 19 & 50,74 & 15.088 & & & \\
Experimental Group & 20 & 69,00 & 10,208 & 37 & 0.000 & -18.263 \\
\hline
\end{tabular}

In the effectiveness test of this study, the instrument was in the form of an environmental awareness questionnaire. The forms of questions is related to the level of concern for the natural environment include: 1) responding to the presence of waste around the environment; 2) Sorting out the types of waste in the environment; 3) attitude tow ards friends in environmental cleanliness; 4) attitude for producing waste; and 5) attitude to manage waste wisely. The questions are answered by students by choosing to agree and disagree options. The results of the measurement of 25 questions in the questionnaire showed that most of the students disagree to negative statements and answered agreeably to positive statements. So, it can be concluded that the addition of an environment-based syllabus will raise the form of a caring attitude tow ards the natural environment.

The results of effectiveness test of the use of syllabus in the table above can be described that there is a different mean from the two groups. The average value obtained for the control group is 50.74 and while the average value for the experimental group is 69.00 with a standard deviation of 15,088 and 10,208. The average value of the control is lower than the experimental class with a difference in the value of 4.88 . The test results in table 7 obtained the value of Sig. (2-tailed) which is $0,000<0.05$ so that means that the use of environment-based syllabus is more effective to increase students' environmental aw areness. The syllabus developed can be an alternative to increase students' aw areness tow ard their environment and widely use to support another aspect of learning in elementary school level.

\section{CONCLUSION}

Syllabus contains the main components of competencies that will be instilled in students through an activity of learning. Activities must be carried out to instill or shape the competency. The teacher has a responsibility to ensure these competencies are already possessed by students. Environmental awareness characters can be integrated into learning in each subject. Learning material related to the values of each subject needs to be developed and explicitly related to the context of everyday life. This character development can be done by integrating indicators contained in the syllabus. Furthermore, the teacher can use the syllabus as a guideline for learning and teaching the students the character of environmental aw areness. In line with the research of Çimen \& Yilmaz (2014), the environmental based syllabus developed in this study is proven can be an alternative learning guideline. The development of the environmental syllabus is based on the local need and sense of local character. That finding also support the study of Erhabora \& Don (2016) which stated that the implementation of such kind of local-based syllabus will truly help the teacher to foster a noble character to students. The development of this syllabus still needs more improvement. Teacher or researcher who are intereested in this area can also develop various learning materials in the same or broaden theme. The implementation in primary level might be succesfull in thematic subject and still be investigated in separated or independent subjects. Thelimitation of this research was the researcher just developed learning syllabus in the form of a guideline and supporting book for teachers. Further developments related to the learning media and source of materials can be executed, especially for serving a special book for students as additional materials. Enlarging the research scale or placing it in different settings will enable this topic broadly discussed.

\section{ACKNOWLEDGMENT}

We thank to all of supported lecturer from Universitas Sebelas Maret who give us insight during this research. We also give our deepest thanks to the headmaster, teachers and all officials of all of state elementary schools in Pasarkliw on subdistrict, Surakarta. 
Purwanti,D., Gunarhadi \& Musadad,A.A. (2019). The effect of local-based 2013 curriculum implementation on students' environmental awareness. International Journal of Educational Research Review, 4(1),65-75.

\section{REFERENCES}

Al-Anwari, A. M. (2014). Strategi Pembentukan Karakter Peduli Lingkungan di Sekolah Adiwiyata Mandiri. TA'DIB, 21(2), 227-252.

Aminrad, Z., Zakariya, S. Z., Hadi, A. S., \& Sakari, M. (2013). Relationship between aw areness, knowledge, and attitudes towards environmental education among secondary school students in Malaysia. World Applied Sciences Journal, 22(9), 1326-1333.

Ardiansyah, R., Suharno, \& Triyanto (2018). Inheritance national culture through learning in elementary school at disruptive era: Case study in Surakarta Indonesia. International Journal of Educational Research Review, 3(4), 48-53.

Bohlin, K. E. (2005). Teaching character education through literature awakening the moral imagination in secondary classrooms. New York: Routledge Falmer.

Borich, G. D. (2007). Effective teaching methods research-based practice: Sixth Edition. New Jersey: Pearson Merrill Prentice Hall.

Branch, R. M. (2009). Instructional design: The ADDIE Approach. New York: Springer.

Çimen, O., \& Yılmaz, M. (2014). The influence of transformative learning based environmental edu cation on pre-service biology teachers' perception of environmental problems. Bartm University Journal of Education Faculty, 3(1), 339-359.

Erhabora, N. I., \& Don, J. U. (2016). Impact of environmental education on the knowledge and attitude of students towards the environment. International Journal of Environmental \& Science Education, 11(2), 5367-5375.

Finn, P. (2011). Critical thinking: Knowledge and skills for evidence-based practice. Language, Speech, and Hearing Services in School, 42, 69-72.

Hamzah, S. (2013). Pendidikan Lingkungan: Sekelumit Wawasan Pengantar. Bandung: Refika Aditama.

Hosnan, M. (2014). Pendekatan Saintifik dan Kontekstual dalam pembelajaran Abad 21. Bogor: Ghalia Indonesia.

Keleş, Ö., Uzun, N., \& Varnac1-Uzun, F. (2010). Evaluating environmental aw areness of teacher candidates, environmental attitudes, thinking and behavior of the project depends on the nature of education exchange and permanence. Electronic Journal of Social Sciences, 9(32), 384-401.

Kemendikbud. (2013). Materi Pelatihan Implementasi Kurikulum 2013. Jakarta: Badan Pengembangan Sumber Daya Manusia dan Kebudayaan dan Penjaminan Mutu Pendidikan.

Kemendikbud. (2013). Peraturan Menteri Pendidikan dan Kebudayaan RI Nomor 67 Tahun 2013 Tentang Kerangka Dasar dan Struktur Kurikulum Sekolah Dasar/Madrasah Ibtidaiyah. Jakarta: Biro Hukum dan Administrasi.

Kemendikbud. (2013). Peraturan Menteri Pendidikandan Kebudayaan Republik Indonesia Nomor 65 Tahun 2013 Standar Proses Pendidikan Dasar dan Menengah. Jakarta: Biro Hukum dan Admnistrasi.

Kutanegara, P. M. (2014). Membangun Masyarakat Indonesia Peduli Lingkungan. Yogyakarta: UGM.

Majid, A., \& Rochman, C. (2015). Pendekatan Ilmiah dalam Implementasi Kurikulum 2013. Bandung: PT. Remaja Rosdakarya.

Mulyatiningsih, E. (2011). Metode Penelitian Terapan Bidang Pendidikan. Bandung: Alfabeta.

Pratomo, A., Sarwanto, \& Roemintoyo. (2018). The development of integrative theme based instructional materials containing characteristics values of fifth grade elementary schools in Surakarta, Indonesia. International Journal of Educational Research Review, 3(3), 39-46.

Saminanto. (2013). Panduan Praktis Mengembangkan RPP PAIKEM Scientific Kurikulum 2013. Semarang: Rasail Media Group. 
Purwanti,D., Gunarhadi \& Musadad,A.A. (2019). The effect of local-based 2013 curriculum implementation on students' environmental awareness. Interna tional Journal of Educational Research Review,4(1),65-75.

Şimşekli, Y. (2004). For the development of environmental aw areness, sensitivity to environmental education activities for primary schools. Journal of Uludă̆ University Faculty of Education, 17(1), 83-92., 17(1), 83-92.

Suyadi. (2013). Strategi Pembelajaran Pendidikan Karakter. Bandung: PT Remaja Rosdakarya Offset.

Trianto. (2010). Model Pembelajaran Terpadu. Jakarta: Bumi Aksara.

Uyanık, G. (2016). Effect of environmental education based on transformational learning theory on perceptions tow ards environmental problems and permanency of learning. International Electronic Journal of Environmental Education, 6(2), 126-140. 